\title{
KINETIKA TRANSPOR Co(II) MELALUI TEKNIK MEMBRAN CAIR FASA RUAH SECARA KONSEKUTIF
}

\author{
Riana Dewi ${ }^{1,2}$, Admin Alif ${ }^{1}$, Hermansyah Aziz ${ }^{1}$ \\ ${ }^{1}$ Pascasarjana Universitas Andalas, Padang \\ ${ }^{2}$ SMAN 1 Padang Sago, Padang Pariaman
}

\begin{abstract}
Determination of kinetic analysis of $\mathrm{Co}$ (II) ion transport through bulk liquid membranes by consecutive method have been study. The optimum condition was obtained at $\mathrm{pH} 4$ for the intermediate phase and receiving phase at $\mathrm{pH}$ near zero, while the source phase at $\mathrm{pH} 7$, oxine concentration in chloroform at source phase is $2.10 \mathrm{M}$, methyl red concentration in chloroform at receiving phase is $3.10 \mathrm{M}$. It was found that $\mathrm{Co}(\mathrm{II})$ ion receiving phase at optimum condition as $4.40 \%$. Evaluation of $\mathrm{Co}(\mathrm{II})$ ion kinetic transport shows $\mathrm{k}_{1}$ as 0.0116 minutes $^{-1}$ and $\mathrm{k}_{4} 0.0113$ minutes $^{-1}$. Kinetic transport process of $\mathrm{Co}$ (I1) ion through bulk liquid membranes by consecutive method followed first order consecutive irreversible reaction rate low. Consecutive method can used as an alternative method in determination the optimum condition of metals ion transport and kinetic evaluation of mentioned transport metals ion.
\end{abstract}

Keywords : bulk liquid membranes, consecutive, cobalt

\section{PENDAHULUAN}

Teknologi membran cair fasa ruah sudah dikenal dengan baik dalam berbagai proses industri. Metodologinya cukup handal dan telah banyak dipublikasikan untuk proses pemurnian dan pemisahan logam. Membran cair fasa ruah merupakan bagian dan teknik yang mampu memberikan seluruh fasilitas antar mukanya untuk dipakai dalam sistem pemisahan $^{[1]}$. Youn ${ }^{[2]}$ telah mempublikasikan metoda ini untuk pemisahan $\mathrm{Co}-\mathrm{Ni}$ dengan menggunakan HEH (EHP) sebagai zat pembawa (carrier). Safavi and Shams ${ }^{[3]}$ juga telah memanfaatkan metoda ini untuk memisahkan $\mathrm{Hg}(\mathrm{II})$ di dalam air dengan memakai metil merah sebagai zat pembawa.

Penelitian sebelumnya dilakukan dengan menggunakan satu fasa sumber, satu fasa membran dan satu fasa penerima ${ }^{[2,3]}$. Pemakaian dua fasa membran yaitu oksin dan metil merah sebagai zat pembawa dalam membran cair fasa ruah secara konsekutif belum pernah dipublikasikan. Dalam penelitian ini orientasi penggunaan oksin dan metil merah yang digunakan secara serentak dan berurutan pada $\mathrm{pH}$ tertentu sangat menarik untuk dipakai dalam pemanfaatannya sebagai zat pembawa Co(II) dan larutan air melalui proses antarfasa.

Penelitian ini bertujuan untuk menentukan apakah sistem konsekutif dapat digunakan untuk transpor $\mathrm{Co}$ (II) dan fasa sumber ke fasa penerima dan bagaimana kinetika reaksi pada proses transpor secara konsekutif.

Mekanisme transpor ion logam $\left(\mathrm{M}^{+\mathrm{n}}\right)$ melalui teknik membran cair fasa ruah secara konsekutif dapat dilihat pada Gambar 1.

Transpor awal ion logam ke fasa membran dimulai dengan reaksi antara ion logam dengan zat pembawa yang terkandung dalam membran/pelarut organik membentuk kompleks tidak bermuatan. Kompleks tidak bermuatan dapat dibentuk diantaranya melalui proses pembentukan khelat (yaitu khelat netral), solvasi atau pembentukan pasangan ion $^{[4]}$. Gaya sentrifugal akibat pengadukan yang dilakukan dengan putaran magnet akan mempercepat ditariknya ion $\mathrm{M}^{+\mathrm{n}}$ dan fasa sumber ke antar muka fasa membran 1 membentuk kompleks yang reversibel dengan oksin seperi yang terlihat pada reaksi 1 . 
$\mathrm{M}\left(\mathrm{H}_{2} \mathrm{O}\right)^{\mathrm{n}+}{ }_{(\mathrm{fs})}+2 \mathrm{H}-\mathrm{Ox}(\mathrm{fm}) \leftrightarrow \mathrm{M}(\mathrm{Ox})_{\mathrm{n}(\mathrm{fm})}+$ $2 \mathrm{H}^{+}(\mathrm{fs})+4 \mathrm{H}_{2} \mathrm{O}$

Ion hidrogen yang diproduksi oleh reaksi diatas berasal dari oksin akan masuk kembali ke fasa sumber, sedangkan $\mathrm{M}^{+\mathrm{n}}$ dengan oksin membentuk kompleks yang tidak bermuatan akan masuk ke dalam fasa membran 1 . Kompleks $\mathrm{M}^{+\mathrm{n}}$ dengan oksin akan mengalami dekompleksasi dengan adanya $\mathrm{H}^{+}$dari fasa intermediet, sehingga $\mathrm{M}^{+\mathrm{n}}$ akan tertarik ke fasa intermediet dan oksin akan kembali ke fasa membran 1.

$$
\begin{aligned}
& \mathrm{M}(\mathrm{Ox})_{\mathrm{n}(\mathrm{fm})} \rightarrow \mathrm{M}^{+\mathrm{n}}{ }_{(\text {antarmuka })}+2 \mathrm{Ox}^{-} \\
& \mathrm{M}^{+\mathrm{n}_{(\text {antarmuka) }}}+2 \mathrm{X}_{(\mathrm{fs})}^{-} \leftrightarrow \mathrm{MX}_{\mathrm{n}(\mathrm{fp})}
\end{aligned}
$$

Di antarmuka fasa intermediet dengan fasa membran 2 terjadi reaksi antara $\mathbf{M}^{+\mathrm{n}}$ dengan metil merah yang berada dalam fasa membran 2, sehingga $\mathrm{H}^{+}$akan kembali ke fasa intermediet dan kompleks $\mathrm{M}^{+\mathrm{n}}$ dengan metil merah akan masuk ke fasa membran 2 .

$\mathrm{M}_{(\mathrm{fi})}^{+\mathrm{n}}+2 \mathrm{H}-\mathrm{MR}_{(\mathrm{fm})} \leftrightarrow \mathrm{M}(\mathrm{MR})_{\mathrm{n}(\mathrm{fm})}+2 \mathrm{H}_{(\mathrm{fi})}^{+}$

Pada antarmuka antara fasa membran 2 dan fasa penerima kembali terjadi reaksi dekompleksasi dan $\mathrm{M}^{+\mathrm{n}}$ akan masuk ke fasa penerima, sedangkan metil merah kembali ke fasa membran 2.

$\mathrm{M}(\mathrm{MR})_{\mathrm{n}(\mathrm{fm})} \rightarrow \mathrm{M}^{+\mathrm{n}}$ (antarmuka) $+2 \mathrm{MR}^{-}$

$\mathrm{M}^{+\mathrm{n}}{ }_{\text {(antarmuka) }}+2 \mathrm{X}^{-}{ }_{(\mathrm{fp})} \leftrightarrow \mathrm{MX}_{\mathrm{n}(\mathrm{fp})}$

Transpor ion logam dari fasa sumber ke fasa penerima diiringi oleh pertukaran ion hidrogen dan fasa penerima ke fasa sumber. Dalam teknik ini sirkulasi ion hidrogen dari fasa penerima ke fasa sumber akan tergantung pada perbedaan $\mathrm{pH}$ kedua fasa tersebut dan merupakan gaya pendorong untuk proses transpor $\mathrm{M}^{+\mathrm{n}}$ dan fasa sumber ke fasa penerima. Disamping itu, ion hidrogen mempunyai fasilitas yang tinggi dalam proses pertukaran ini karena jari-jari dan massanya yang kecil ${ }^{[5,6]}$.

Metoda pemisahan ion logam dengan teknik membran cair fasa ruah secara konsekutif merupakan teknik pemisahan secara Safavi secara dua tahap. Fasa penerima pada tahap pertama akan menjadi fasa sumber pada tahap kedua selanjutnya dinamakan fasa intermediet. Proses transpor ion logam dengan teknik membran cair fasa ruah secara konsekutif dapat dilihat pada Gambar 1.

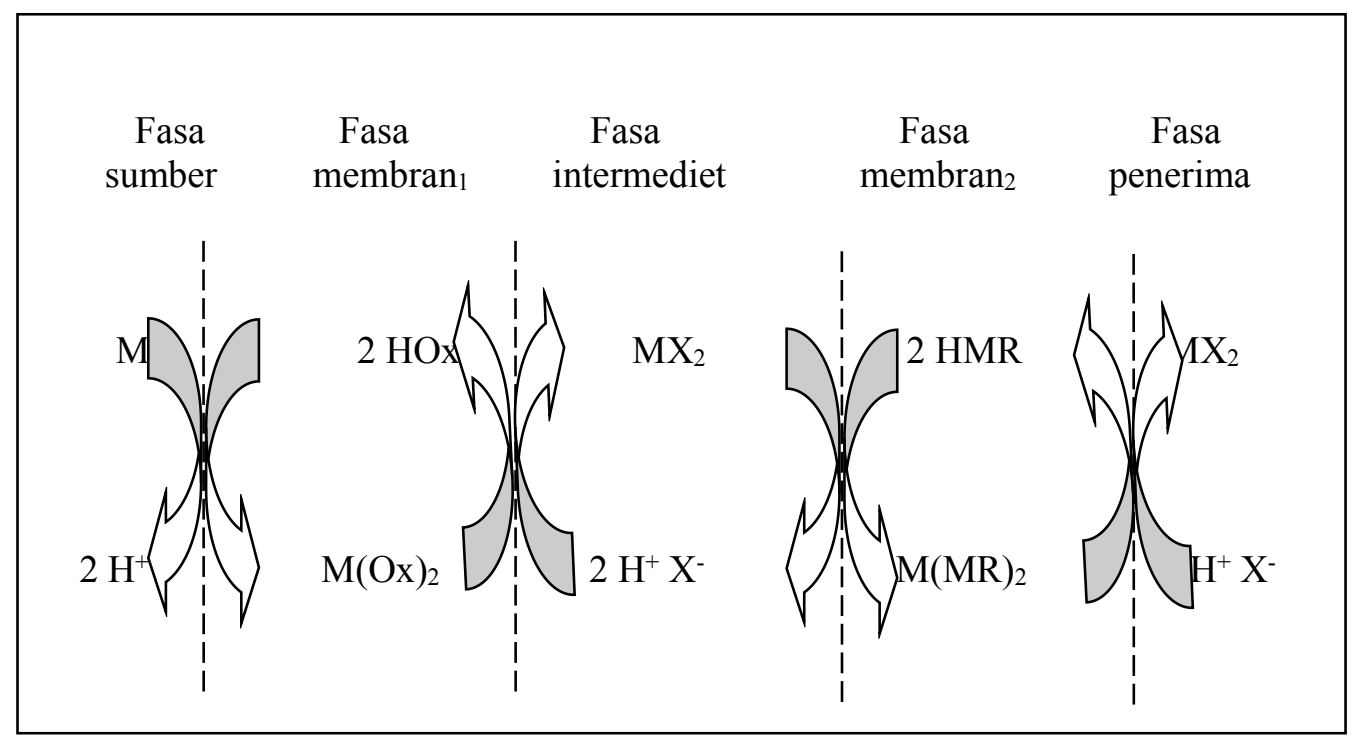

Gambar 1. Mekanisme transpor ion logam melalui teknik membran cair fasa ruah secara konsekutif 
Perubahan konsentrasi $\mathrm{M}^{+\mathrm{n}}$ terhadap waktu diukur secara langsung pada fasa sumber $\left(\mathrm{C}_{\mathrm{s}}\right)$ dan fasa penerima $\left(C_{p}\right)$. Perubahan konsentrasi yang sesuai dalam membran ditentukan dan kesetimbangan ${ }^{[7]}$. Hal ini analog dengan 2 fasa membran + fasa intermediet $\left(\mathrm{C}_{\text {mim }}\right)$ dan teknik membran cair fasa ruah secara konsekutif. Secara praktis untuk perubahan perbandingan konsentrasi setiap waktu dapat digunakan rumus 7 .

$$
R_{s}=\frac{C s}{C s^{o}} \quad R_{\min }=\frac{C_{\min }}{S c^{o}} \quad R_{p}=\frac{C p}{C s^{o}}
$$

Dimana, $\mathrm{Cs}^{\circ}=$ konsentrasi $\mathrm{M}^{+\mathrm{n}}$ awal dalam fasa sumber saat $t=0$.

Secara teori, gambaran perubahaan konsentrasi $\mathrm{M}^{+\mathrm{n}}$ setiap waktu transport dalam fasa sumber $\left(R_{\mathrm{s}}\right)$, dalam 2 fasa membran + fasa intermediet $\left(\mathrm{R}_{\mathrm{mim}}\right)$ dan dalam fasa penerima $\left(\mathrm{R}_{\mathrm{p}}\right)$ dapat dinyatakan :

$$
\mathrm{R}_{\mathrm{s}}+\mathrm{R}_{\operatorname{mim}}+\mathrm{R}_{\mathrm{p}}=1
$$

Mekanisme transpor ion logam pada Gambar 1 dapat disederhanakan seperti berikut:

$\mathrm{S} \stackrel{k_{1}}{\longrightarrow} \mathrm{m}_{1} \stackrel{k_{2}}{\longrightarrow} \mathrm{i} \stackrel{k_{3}}{\longrightarrow} \mathrm{m}_{2} \stackrel{k_{4}}{\longrightarrow} \mathrm{p}$

dimana $\mathrm{s}, \mathrm{m}_{1}, \mathrm{i}, \mathrm{m}_{2}$ dan $\mathrm{p}$ adalah ion $\mathrm{M}^{+\mathrm{n}}$ dalam fasa sumber, fasa membran 1 , fasa intermediet, fasa membran 2 dan fasa penerima. Karena sulitnya menentukan jumlah ion $\mathbf{M}^{+\mathrm{n}}$ yang terdapat pada masing-masing fasa membran, dalam hal ini yang ditentukan hanya $\mathrm{k}_{1}$ dan $\mathrm{k}_{4}$. Skema kinetik dapat dijelaskan dengan persamaan dibawah ini :

$$
\begin{aligned}
& \frac{d R_{s}}{d t}=-k_{1} R_{s}=J_{s} \\
& \frac{d R_{\text {mim }}}{d t}=\mathrm{k}_{1} \mathrm{Rs}-\mathrm{k}_{4} \mathrm{Rmim} \\
& \frac{d R_{p}}{d t}=\mathrm{k}_{4} \mathrm{Rm}=\mathrm{Jp}
\end{aligned}
$$

Terlihat bahwa bahwa $\mathrm{R}$ vs $\mathrm{t}$ menghasilkan kurva penurunan monoeksponensial sedangkan $\mathrm{R}_{\text {mim }}$ dan $\mathrm{R}_{\mathrm{p}}$ adalah merupakan kurva bieksponensial dan bukan merupakan kurva linier ${ }^{[8]}$.

\section{METODOLOGI}

\section{Alat dan Bahan}

Alat yang dipakai adalah spektrofotometer serapan atom (AAS) Model ALFA-4 London Inggris, indikator universal merck KgaA 64271 Darmstadt German, neraca analitik Ainsworth dan stop-watch, magnetik stirer, magnetik bar dan sel membran cair fasa ruah konsekutif.

Bahan-bahan yang digunakan umumnya spesifikasi pa antara lain : kloroform, oksin, metil merah, $\mathrm{CoCl}_{2} \cdot 6 \mathrm{H}_{2} \mathrm{O}$, akuabides, $\mathrm{HCl}$, $\mathrm{HNO}_{3}, \mathrm{NH}_{4} \mathrm{OH}$, dan larutan buffer.

\section{Prosedur}

Ke dalam salah satu dari reaktor sel membran (Gambar 2) dimasukkan $50 \mathrm{~mL}$ larutan fasa membran yang mengandung oksin dan pada bagian yang lain $50 \mathrm{~mL}$ fasa membran yang mengandung metil merah. Kedalam masingmasingnya dicelupkan sebuah tabung selinder. Kemudian kedalam salah satu tabung tersebut dimasukkan $15 \mathrm{~mL}$ fasa sumber dengan $\mathrm{pH} 7$ dan pada tabung yang lain $15 \mathrm{~mL}$ fasa penerima dengan $\mathrm{pH}$ mendekati nol. Pada bagian luar tabung silinder dimasukkan 150 $\mathrm{mL}$ fasa intermediet. Membran (lapisan kloroform) diaduk dengan magnetik stirer yang telah dilapisi teflon selama 5 jam. Setelah didiamkan selama 15 menit fasa sumber, fasa intermediet dan fasa penerima diambil masingmasing $1 \mathrm{~mL}$ dan diencerkan dengan akuabides sampai volumenya $5 \mathrm{~mL}$. Sebelum mencapai tanda batas ditambahkan 3 tetes $\mathrm{HNO}_{3}$ pekat. Pengukuran konsentrasi $\mathrm{Co}(\mathrm{II})$ yang terkandung didalamnya diukur dengan spektrofotometer serapan atom (AAS) dengan bantuan kalibrasi dan larutan standar.

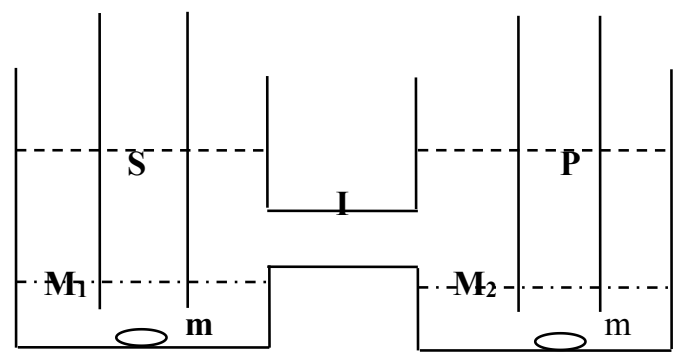

Gambar 2. Sel membran cair fasa ruah secara konsekutif dimana $\mathrm{S}=$ fasa sumber, $\mathrm{I}=$ fasa intermediet, $\mathrm{P}=$ fasa penerima, $\mathrm{M}_{1}$ dan $\mathrm{M}_{2}=$ fasa membran, sedangkan $\mathrm{m}=$ magnetik bar 


\section{HASIL DAN PEMBAHASAN}

\section{Pengaruh Letak Membran}

Transpor Co(II) dari fasa sumber ke fasa penerima dilakukan melalui pembentukan kompleks yang relatif lebih stabil antar fasa membran yaitu antara $\mathrm{Co}(\mathrm{II})$ dengan oksin dalam kloroform dan $\mathrm{Co}(\mathrm{II})$ dengan metil merah juga dalam kloroform di bawah pengaruh $\mathrm{pH}$ dan fasa sumber, fasa intermediet dan fasa penerima. Melalui pengaturan letak membran maka $\mathrm{Co}$ (II) akan tertarik dari fasa sumber ke fasa penerima ${ }^{[9]}$.

Terlihat bahwa transpor $\mathrm{Co}(\mathrm{II}) \mathrm{ke}$ fasa penerima lebih optimum adalah dengan letak membran kloroform yang mengandung oksin berkontak dengan fasa sumber dan kloroform yang mengandung metil merah yang berkontak dengan fasa penerima. Pada kondisi ini Co(II) yang tersisa pada fasa sumber relatif kecil yaitu $35,12 \%$ dan $\mathrm{Co}$ (II) pada fasa intermediet cukup tinggi yaitu $39,14 \%$ walaupun yang sampai ke fasa penerima hanya $3,74 \%$. Hal ini disebabkan $\mathrm{pH} 7$ pada fasa sumber cocok untuk ekstraksi ion logam $\mathrm{Co}(\mathrm{II})$ dengan menggunakan zat pembawa oksin dalam kloroform dan $\mathrm{pH} 4$ pada fasa intermediet cocok untuk ekstraksi menggunakan metil merah sebagai zat pembawa. Dalam hal ini dapat disimpulkan bahwa kompleks yang terbentuk antara $\mathrm{Co}(\mathrm{II})$ dengan metil merah lebih stabil dan pada kompleks Co(II) dengan oksin $^{[10]}$.

\section{Pengaruh Konsentrasi Oksin Dalam Fasa Membran}

Terjadinya transpor suatu ion logam melaiui membran yang menggunakan zat pembawa ada1ah melalui pembentukan kompleks yang tidak bermuatan yang bersifat reversibel sehingga mampu berdifusi melalui membran dan mudah terdekompleksasi pada antar muka fasa membran 1 dengan fasa intermediet. Pengaruh konsentrasi oksin terhadap transpor ion Co(II) diperlihatkan pada Gambar 3.

Tabel 1. Pengaruh Letak Membran terhadap Transpor Co(II) dari Fasa Sumber ke Fasa Penerima

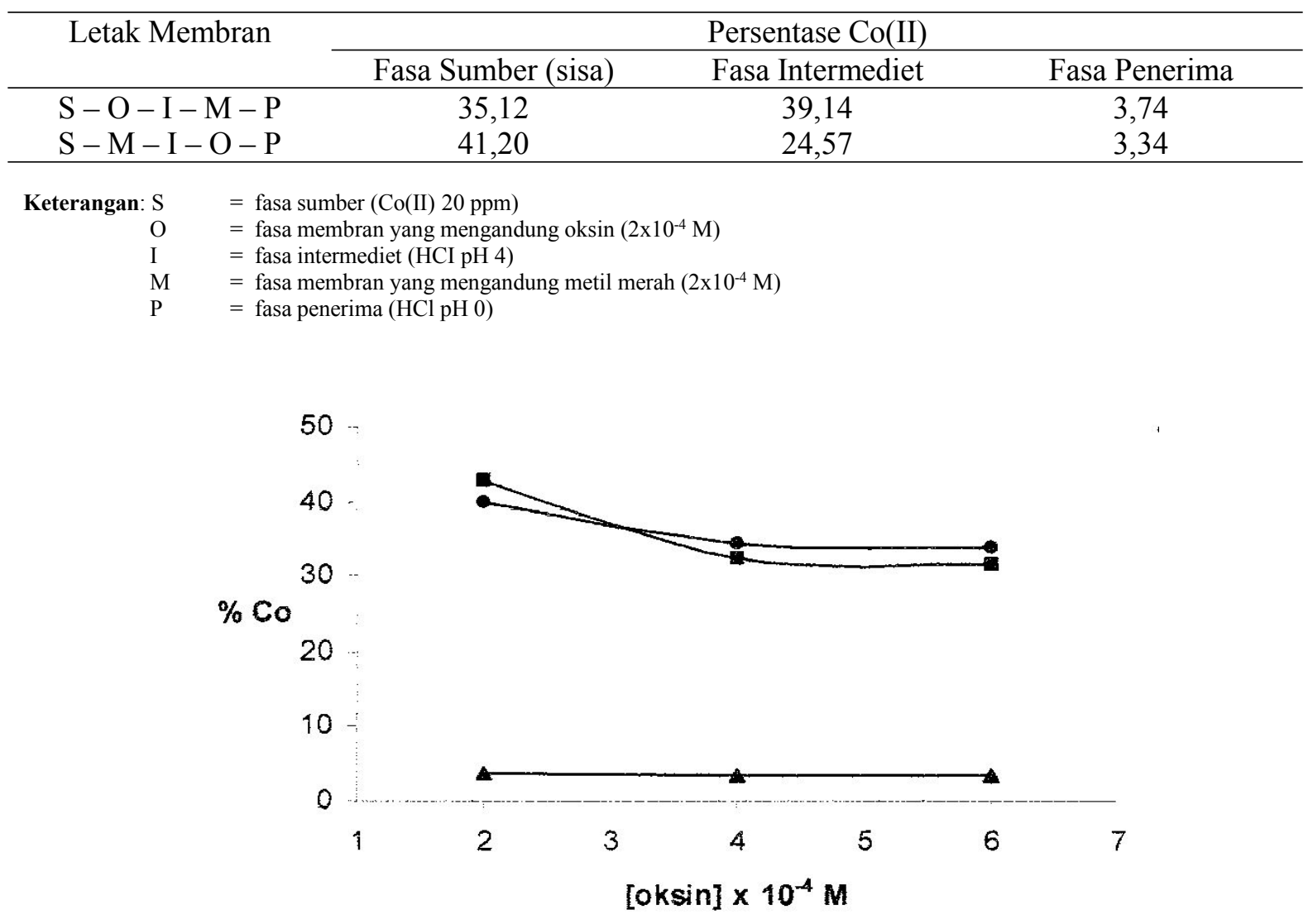

Gambar 3. Pengaruh konsentrasi oksin dalam fasa membran terhadap persentase Co(II) dalam fasa sumber $(\bullet)$, fasa intermediet $(\boldsymbol{\bullet})$, dan fasa penerima $(\boldsymbol{\Delta})$ 


\section{Pengaruh pH Fasa Intermediet}

Gambar 4 memperlihatkan transpor $\mathrm{Co}$ (II) optimum ke fasa penerima berlangsung pada $\mathrm{pH}$ intermediet $=4$. Pada daerah $\mathrm{pH}$ ini $\mathrm{Co}$ (II) yang tersisa dan fasa sumber $35,62 \%$ dan tertranspor ke fasa penerima $4,23 \%$. Semakin besar $\mathrm{pH}$ intermediet, semakin banyak Co(II) tersisa pada fasa sumber, dan semakin sedikit $\mathrm{Co}(\mathrm{II})$ yang tertarik ke fasa intermediet. Hal ini disebabkan karena perbedaan $\mathrm{pH}$ fasa intermediet dengan $\mathrm{pH}$ fasa sumber semakin kecil sehingga daya tarik dari fasa intermediet semakin lemah. Pada $\mathrm{pH}$ intermediet lebih besar dan 4 terjadi penurunan transpor ion Co(II) yang sampai ke fasa penerima, karena Co(II) yang sampai ke fasa intermediet berkurang maka yang akan ditranspor ke penerima juga berkurang. Kemungkinan lain juga karena protonasi yang tidak sempurna dan zat pembawa yang terjadi pada antar muka antara fasa membran 2 dan fasa penerima ${ }^{[13]}$.

\section{Pengaruh Konsentrasi Metil Merah Dalam Fasa Membran}

Pembentukan kompleks yang tidak bermuatan antara $\mathrm{Co}(\mathrm{II})$ dengan metil merah sangat dipengaruhi oleh konsentrasi metil merah. Dari Gambar 5 terlihat bahwa konsentrasi metil merah yang optimum terjadi pada konsentrasi $3 \times 10^{-4} \mathrm{M}$. Pada konsentrasi $1 \times 10^{-4} \mathrm{M}$ sampai dengan $3 \times 10^{-4} \quad \mathrm{M}$ jumlah $\mathrm{Co}$ (II) yang tertranspor ke fasa penerima meningkat dari $2,65 \%$ menjadi $4,25 \%, \mathrm{Co}$ (II) tersisa pada fasa sumber $24,73 \%$ dan yang tertranspor ke fasa intermediet $33,11 \%$.

Kelebihan konsentrasi metil merah lebih lanjut menyebabkan $\mathrm{Co}(\mathrm{II})$ yang tertranspor ke fasa penerima semakin sedikit ${ }^{[3]}$. Hal ini disebabkan banyaknya ion $\mathrm{Co}$ (II) yang terperangkap dalam fasa membran karena kompleks bersifat stabil, sehingga proses dekompleksasi atau pecahnya kompleks Co-metil merah akibat adanya ion $\mathrm{H}^{+}$pada fasa penerima menjadi lambat ${ }^{[14]}$.

\section{Penentuan Waktu Transpor}

Menurut Molina et al., faktor pengadukan sangat mempengaruhi interaksi tumbukan antar molekul dalam memperlancar terjadinya proses difusi. Berdasarkan Gambar 6 dapat dilihat bahwa semakin lama waktu transpor, persentase $\mathrm{Co}(\mathrm{II})$ yang tersisa di fasa sumber semakin berkurang, sedangkan pada fasa intermediet semakin naik sampai waktu 60 menit, selanjutnya dengan berjalannya waktu terjadi penurunan. Pada fasa penerima terjadi peningkatan sampai waktu 60 menit dengan jumlah $\mathrm{Co}(\mathrm{II})$ yang tertranspor dan 2,50\% sampai $4,40 \%$, setelah itu penambahan waktu tidak mempengaruhi transpor $\mathrm{Co}(\mathrm{II})^{[15]}$.

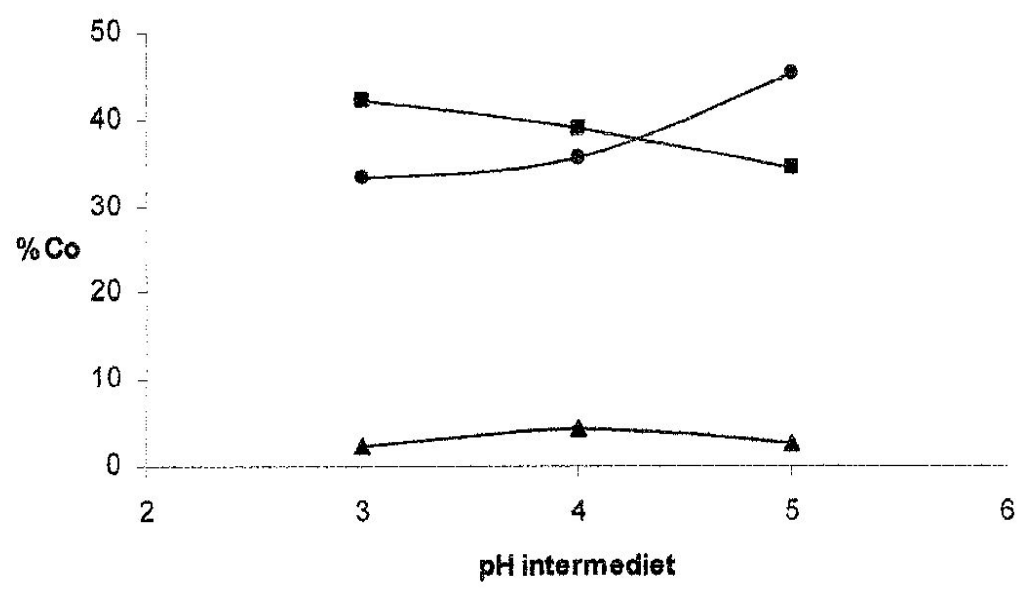

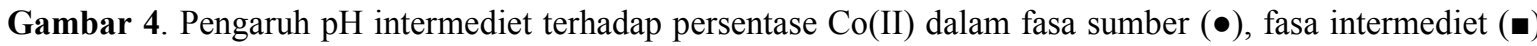
dan fasa penerima 


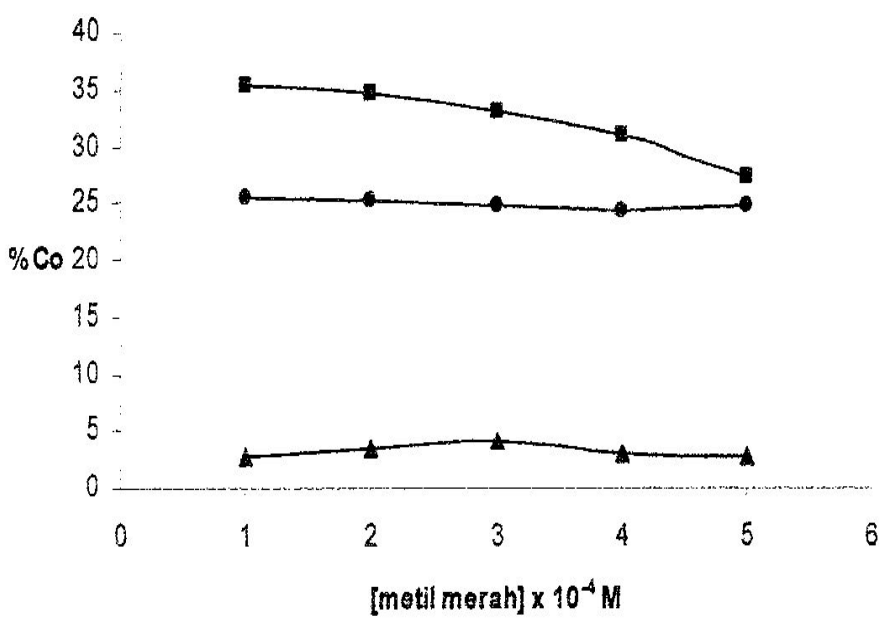

Gambar 5. Pengaruh konsentrasi metil merah terhadap persentase Co(II) dalam fasa sumber (•), fasa intermediet ( $\mathbf{\square})$ dan fasa penerima $(\boldsymbol{\Delta})$

Waktu optimum yang didapatkan adalah 4 jam, karena setelah waktu 4 jam baik Co(II) yang tersisa pada fasa sumber maupun yang tertranspor $\mathrm{ke}$ fasa intermediet dan fasa penerima mencapai keadaan setimbang ditandai dengan tidak terjadinya perubahan jumlah Co(II) pada masing-masingnya.

\section{Penentuan Kinetika Transpor Co(II) dari Fasa Sumber ke Fasa Penerima}

Hubungan perubahan perbandingan konsentrasi terhadap waktu transpor dapat dilihat pada Gambar 7. Perubahan konsentrasi Co(II) dalam fasa sumber (Rs) menurun secara eksponensia1 ${ }^{[17]}$, sedangkan perubahan konsentrasi $\mathrm{Co}$ (II) pada dua fasa membran dan fasa intermediet meningkat dan perubahan konsentrasi $\mathrm{Co}$ (II) pada fasa penerima juga meningkat ${ }^{[11]}$. Setelah waktu 4 jam terjadi kesetimbangan penurunan konsentrasi $\mathrm{Co}$ (II) pada fasa sumber $\mathrm{R} 0,2102$, pada fasa intermediet dan 2 fasa membran Rmim 0,7536 dan fasa penerima $\operatorname{Rp~} 0,0362$.

$\mathrm{k}_{1}$ adalah konstanta kecepatan transpor $\mathrm{Co}(\mathrm{II})$ masuk ke fasa membran 1 dan $\mathrm{k}_{4}$ adalah konstanta kecepatan transpor Co(II) keluar ke fasa penerima dan fasa membran 2 (atau fasa gabungan), dan hasil perhitungan didapatkan harga $\mathrm{k}_{1}$ adalah 0,0116 menit $^{-1}$ sedangkan nilai $\mathrm{k}_{4}$ adalah 0,0113 menit $^{-1}$. Nilai $\mathrm{k}_{1}$ lebih besar dibandingkan nilai $\mathrm{k}_{4}$ sehingga dapat diasumsikan bahwa kecepatan transpor $\mathrm{Co}$ (II) yang masuk pada membran 1 dari fasa sumber lebih cepat dibandingkan kecepatan transpor $\mathrm{Co}(\mathrm{II})$ yang masuk ke fasa penerima.

\section{KESIMPULAN}

Kondisi optimum transpor Co(II) dengan menggunakan teknik membran cair fasa ruah secara konsekutif dengan menggunakan oksin dan metil merah sebagai pembawa dilakukan pada $\mathrm{pH}$ fasa sumber 7 dan $\mathrm{pH}$ fasa penerima mendekati nol. Kondisi yang diperoleh adalah dengan letak membran kloroform yang mengandung oksin berkontak dengan fasa sumber dan membran kloroform yang mengandung metal merah berkontak dengan fasa penerima. Sedangkan kondisi optimum konsentrasi oksin dalam kloroform adalah $2 \times 10^{-4} \mathrm{M}, \mathrm{pH}$ intermediet 4 . Konsentrasi metil merah dalam kloroform adalah $3 \times 10^{-4} \mathrm{M}$. Pada kondisi ini persentase transpor $\mathrm{Co}$ (II) ke fasa penerima baru mencapai $40 \%$. 


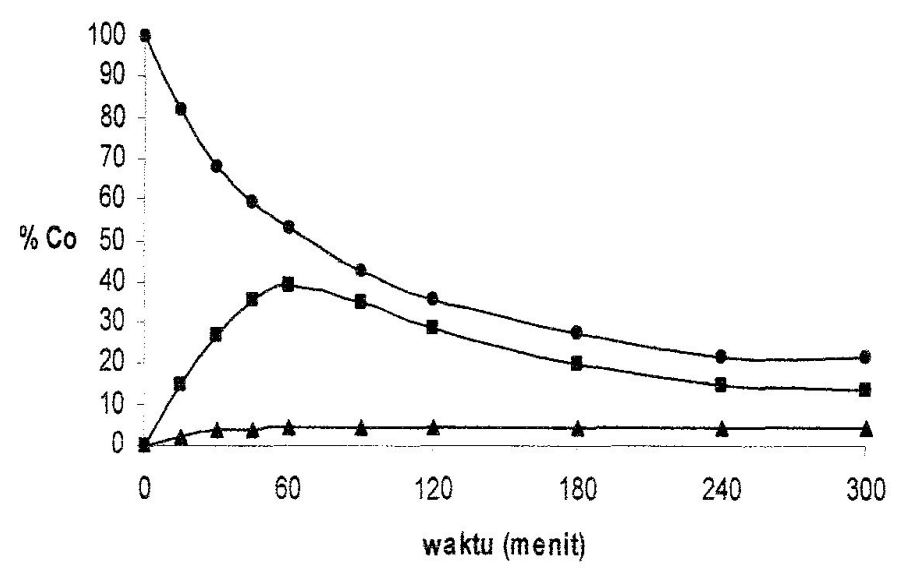

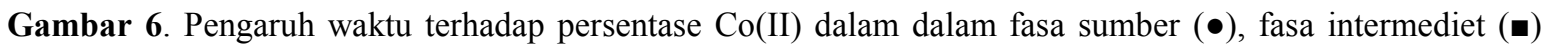
dan fasa penerima (

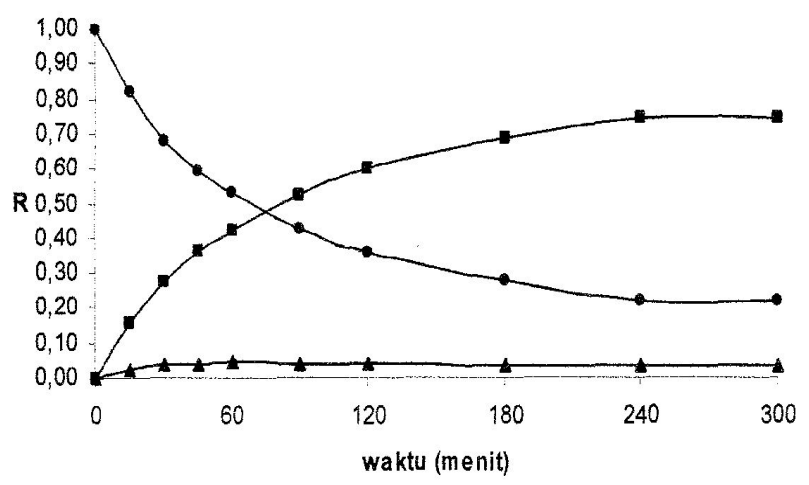

Gambar 7. Pengaruh lamanya waktu transpor terhadap penurunan persentase Co(II) dalam fasa sumber Rs $(\bullet)$, fasa membran + intermediet + membran $\operatorname{Rmim}(\boldsymbol{\bullet})$ dan fasa penerima $\operatorname{Rp}(\boldsymbol{\Delta})$

\section{DAFTAR PUSTAKA}

1. M. Mulder, Basic Principle of Membrane Technology, Kluwer Academic Publisher, Dordrecht, 1991, 244-259.

2. I. J. Youn., Y. lee, J. Jeong, W. H. Lee, Analysis of Co-Ni Separation by a Supported Liquid Membrane Containing HEH (EHP), J. Membr. Sci., 125: 231-236, (1997).

3. A. Safavi, and E. Shams, Selective and Efficient Transport of $\mathrm{Hg}(\mathrm{II})$ Through Bulk Liquid Membrane Using Methyl Red as Carrier, J. Membr. Sci., 144: 37-43, (1998).

4. S. M. Khopkar, Konsep dasar Kimia Analitik, UI Press, Jakarta, 1990, 71-107.

5. Z. Kahar, Transpor Co(II) Antarfasa (AirKloroform-Air) Melalui Teknik Membran Cair Fasa Ruah, J. Kimia Andalas, 7(2): 71-79, (2001).
6. Z. Kahar, Optimalisasi Transpor Co(II) Dengan zat Pembawa Oksin, Melalui Teknik Membran Cair Fasa Ruah, Tesis Pascasarjana Kimia Unand, 2001.

7. D. He, M. Ma, Z. Zhao, Transport of Cadmium ions Through a Liquid membrane Containing Amina Extractants As Carriers, J. Membr. Sci., 169: 53-59, (2000).

8. S. Altin, N. Demircioglu, I. A. Peker Altin, Effect of acceptor phase and donor phase properties on sodium ions transport from aqueous solutions using liquid membrane systems, J. Colloids and Surfaces, 143(69): $1-8,(2007)$.

9. C. Aydiner, M. Kobya, E. Demirbas, Cyanide Ion Transport from Aqueous Solutions by Using Quaternary Ammonium Salt Through Bulk Liquid Membrane, J. Desalination, 180: 139-150, (2005). 
10. Sukardjo, Kimia Koordinasi, Penerbit Rineka Cipta, Jakarta, 1992, 101-111

11. H. K. Alpoguz, S. Memon, M. Ersoz, and M. Yilmaz, Transport of $\mathrm{Hg}^{2+}$ Through Bulk Liquid Membrane Using a bis-calix[4] arene nitrile Derivative As Carrier: Kinetic Analysis, New. J. Chem., 26: 477-480, (2002).

12. K. Hiratani, T. Takahashi, FL. Sugihara, H. Kasuga, K. Fujiwara, T. Hayashita, R. A. Bartsch, Selective Liquid Membrane Transport of Lead(1I) by an Acyclic Polyether Dicarboxylic Acid lonophore, $J$. Anal. Chem., 69: 3002-3007, (1997).

13. A. O. Saf, Alpaydin, S. A. Sirit, Transport Kinetics of Chromium (VI) ions Through a Bulk Liquid membrane Containing ptert-butyl calix[4] arene 3-morpholino propyl diamide Derivate, J. Membr Sci., 283: 448-455, (2006).

14. A. Alif, A. Amran, H. Aziz dan I. Pelita, Permiasi Ni(II) Melalui Membran Cair
Fasa Ruah dengan Oksin sebagai Pembawa, J. Kimia Andalas, 7(2): 61-64, (2001).

15. A. Safavi, and E. Shams, Selective Transport of Silver Ions Through Bulk Liquid membrane Using Victoria Blue as Carrier, J. of Talanta, 48: 1167-1172, (1999).

16. M. R. Yaftian, A. A. Zamani, and S. Rostamnia, Thorium (IV) Ion-Selective Transport Through A Bulk Liquid Membrane Containing 2-Thenoyltrifluoroacetone As Extractant-Carrier, $J$. Separation and Purification Tech., 49: 7175, (2006).

17. G. Leon, and M. A. Guzman, Facilitated transport of cobalt through bulk liquid membranes containing dietylhexyl phosphoric acid, J. Desalination, 162: 211215, (2004). 